\title{
Riverine dominance of a nearshore marine demersal food web: evidence from stable isotope and $\mathrm{C} / \mathrm{N}$ ratio analysis
}

\author{
A.M. de Lecea, A.J . Smit and S.T. Fennessy
}

\begin{abstract}
The Thukela Bank, KwaZulu-Natal, supports a diverse ecosystem and South Africa's only prawn fishery. Oceanographic studies suggest riverine input is not important for the biology of this system, whereas biological studies suggest the contrary, with prawn catches increasing with increased fluvial run-off. The aim of this study was to determine (i) the importance of riverine and marine organic matter for the Thukela Bank food web; and (ii) whether there are seasonal changes in the Thukela River stable isotope values, and, if so, whether these are reflected in the isotope values of demersal organisms. Estuarine organic matter, sediments and demersal organisms were collected from several sites across the bank in the wet and dry seasons of 2008, 2009 and 2010. Marine particulate organic matter was also collected in 2010 and analysed for $\delta 13 \mathrm{C}$ and $\delta 15 \mathrm{~N}$, as well as $\mathrm{C} / \mathrm{N}$ ratios. There were strong seasonal changes in isotopic values of organic matter and fauna, especially faunal $\delta 13 \mathrm{C}$. There was an apparent time-lag in organisms assimilating riverine organic matter isotopic values, with the isotopic signature of demersal organisms reflecting that of riverine organic matter from the previous season, which is likely the result of tissue turnover time. In 2010, Thukela Bank sediment organic matter was of riverine origin and this maintained the demersal food web. We conclude that Thukela River organic matter is an important input to the food web of the Thukela Bank, indicating that any future damming of the catchment area could have serious consequences for this ecosystem.
\end{abstract}

\section{Introduction}

It is well established that rivers play an important role in the local neritic environment by introducing organic matter (OM) and shaping the overall ecology (e.g. Beaulieu 2002; Gillanders and Kingsford 2002). Terrigenous allochthonous material is one of the most important sources of nutrients for primary and secondary productivity in the neritic zone (Polis and Hurd 1996), and contributes to enhancing the overall productivity of these systems (Maslowski 2003). Studies have shown that changes in the riverine input can affect individual species as well as entire communities (Serrano et al. 2010; Olin et al. 2013). A large number of studies worldwide have demonstrated that inshore fisheries are dependent on terrigenous inputs (Darnaude et al. 2004; Darnaude 2005). On the east coast of South Africa, there are inshore fisheries on the Thukela Bank (henceforth referred to as 'the bank'), a shallowwater bank formed by muddy sediment discharges of the Thukela River, extending north- and eastwards across the KwaZulu-Natal (KZN) Bight ('the bight') from the river 
mouth (Figure 1). The bank's fisheries include commercial and recreational linefishing and South Africa's only shallow-water penaeid prawn trawl fishery (Fennessy and Groeneveld 1997; Lamberth et al. 2009). Turpie and Lamberth (2010) demonstrated that, during scenarios of low freshwater input from the Thukela River, prawn-trawl catches dropped by up to c. $11 \%$, suggesting that riverine nutrient sources drive secondary productivity and hence influence fisheries yields. De Lecea et al. (2013) concluded that the estuaries were the main biological drivers of the benthic ecosystem of the bight. Similarly, de Lecea et al. (2015) concluded that riverine input played a major role driving the pelagic zooplankton food webs near shore, including in the Thukela Bank area. Lamberth et al. (2009) suggested that any major development that reduces water flow could dramatically reduce linefishery catches on the bank. Consequently, if any future impoundments, such as those suggested by the former South African Department of Water Affairs and Forestry (DWAF 2004) should occur, then there is a need to understand the extent of dependence of organisms on the bank on OM inputs from the Thukela River.

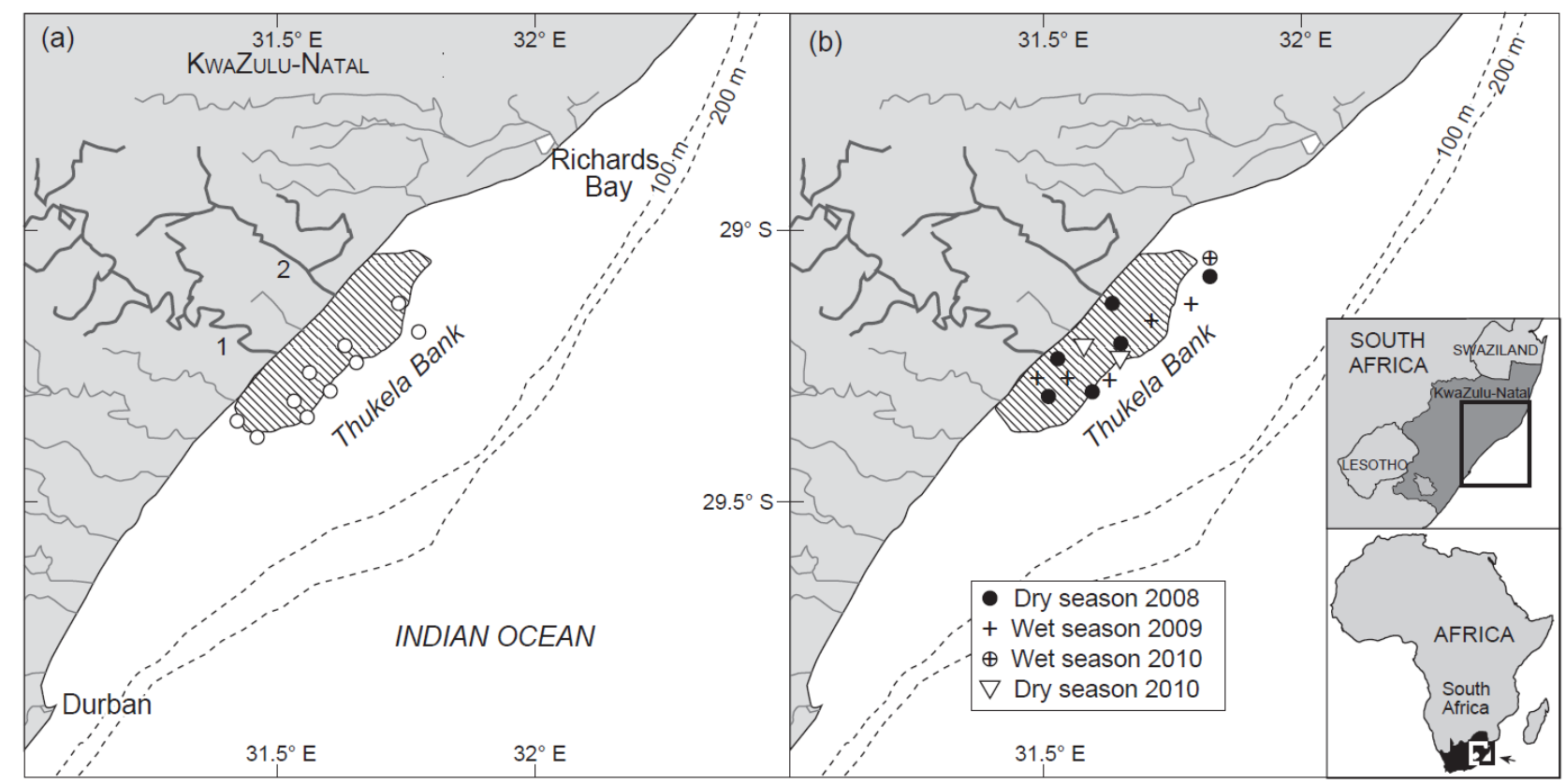

Figure 1: Map of the KwaZulu-Natal Bight showing the Thukela River mouth and the Thukela Bank, as well as (a) sediment stations and (b) trawl sampling locations. The Thukela River (1) and the Matigulu River (2) are shown

Despite this apparent food-web link between terrigenous allochthonous OM and nutrient sources and productivity in the bank region, riverine input into the bight has not been considered as a major factor affecting the region's ecosystem processes (Lutjeharms et al. 2000; Hutchings et al. 2010), but it has been recognised that flooding events have the potential to influence shelf water temporarily (Meyer et al. 2002). It has been accepted that the most important hydrodynamic phenomenon dominating the bight (including the bank), in terms of nutrient input and associated productivity, is an upwelling cell that occurs intermittently, but persistently, in the northern part of the bight where higher concentrations of nutrients are found in association with upwelling events (Meyer et al. 2002). Nevertheless, the Thukela River accounts for more than $35 \%$ of the fresh water entering the entire KZN 
coastline (Bosman et al. 2007; Hutchings et al. 2010). In addition, the fact that the Thukela Estuary is functionally a river mouth rather than a true estuary indicates that most nutrients/ organic matter in its outflow are exported to coastal waters (Lamberth et al. 2009) rather than being trapped and deposited in the estuarine system. Similar suggestions were made by Whitfield (2005), who concluded that, during periods of high-flow conditions, the estuarine zone may be pushed out to sea. Combined with the fact that the bight is oligotrophic (Bustamante et al. 1995; de Lecea and Cooper 2016), this raises the question of whether OM input from the Thukela River and other estuaries within the region could be important for the bight ecosystem. Our study examines the isotopic values of selected marine organisms as well as particulate OM (POM) and OM trapped in the sediments from the Thukela Estuary and the estuary of the nearby, smaller Matigulu River, and from the bank immediately adjacent to those rivers (Figure 1 ). We used stable isotopes ( $813 \mathrm{C}$ and $\delta 15 \mathrm{~N}$ ) and carbon/nitrogen $(\mathrm{C} / \mathrm{N})$ elemental ratios to examine the origin of $\mathrm{OM}$ in the bank region and to investigate whether there are any seasonal isotopic changes that manifest in the tissues of organisms on the bank. We hypothesised that estuarine OM input, which occurs continuously but with episodic and predominant flood events during the wet austral summer, (i) is a main food source for the benthic food web for both wet and dry seasons and (ii) has strong seasonal differences in its stable isotope composition and $\mathrm{C} / \mathrm{N}$ ratios. We also hypothesised that (iii) seasonal isotopic changes can be measured in demersal organisms on the bank. Stable isotopes have previously been used successfully to describe the origin of OM in aquatic systems and the food webs associated with them (Lara et al. 2010; Pomerleau et al. 2011; de Lecea et al. 2013; Olin et al. 2013), and have also been used to develop an understanding of seasonality within estuaries (Harmelin-Vivien et al. 2010; Olin et al. 2013). Furthermore, the understanding gained using stable isotope analysis can be strengthened using $\mathrm{C} / \mathrm{N}$ ratios, because these have the potential to provide information on the origin of OM trapped $n$ sediments (i.e. marine vs terrestrial) (Lamb et al. 2006). The combined use of both datasets can be useful to distinguish further the origin of $\mathrm{OM}$ because different plants have very specific isotope value and $\mathrm{C} / \mathrm{N}$ ratio combinations (Lamb et al. 2006). De Lecea et al. (2013) used this approach to distinguish the origin of OM in the sediments of the entire KwaZulu-Natal Bight and found the north and south edges of the bight to be dominated by marine POM input, a consequence of the marine oceanographic processes occurring in those regions.

\section{Material and methods \\ Study site}

The Thukela Bank is a mud bank off the Thukela River, located in the north-east of the KZN Bight, that encompasses an area of c. $560 \mathrm{~km} 2$ and extends c. $16 \mathrm{~km}$ offshore (Fennessy and Groeneveld 1997). (For information on the oceanography of the bight see Lutjeharms et al. 2000.) Linefishing occurs on reefs in the bank region, and the bank supports South Africa's only shallow-water prawn trawl fishery (Fennessy and Groeneveld 1997; Lamberth et al. 2009). The commercial inshore prawn fishery, the location of which includes the Thukela Bank, had an annual average catch (including bycatch) of $397 \mathrm{t}$, valued at over R 8.5 million (South African rands; 1US\$ = R 6.40 [2003 exchange rate]), for the period 1992-2002 (Turpie and Lamberth 2010). The linefishery has a commercial and recreational boat-based 
component; the commercial component had average total annual landings of $291 \mathrm{t}$, valued at R 28.9 million, for the northern part of the bight, including the bank, over the period 19852001 (Lamberth et al. 2009). Sediment accumulating on the bank comprises poorly sorted sand close to the Thukela River mouth, with the majority of the bank, from the river mouth to the c. $50 \mathrm{~m}$ isobath, formed by mud settling out of the suspended fluvial load (Bosman et al. 2007). A series of fluvially induced processes occur within the bight, dominated by the Thukela River, with an annual flux of $3865 \times 109 \mathrm{~m} 3$ and an annual average sediment input into the bight of $6.79 \times 106 \mathrm{~m} 3 \mathrm{y}-1$ (Bosman et al. 2007). Unlike other estuaries in the region, the Thukela is permanently open to the sea (de Lecea and Cooper 2016). The vegetation surrounding the catchment comprises woodlands, coastal forest, montane forest, thicket and grasslands (predominantly C3 plants) (Fairbanks and Benn 2000), but sugarcane monoculture (a $\mathrm{C} 4$ plant) is also present in the agriculturally transformed catchment area (Dominy et al. 2001). The smaller Matigulu Estuary has a catchment area of $900 \mathrm{~km} 2$ and is fed by the Nyoni and Matigulu rivers (O'Brien et al. 2009). This estuary was chosen for this study due to its proximity to the bank, with its mouth positioned close to the northern end. It is the third-largest source of sediment entering the bight and it has an annual run-off of $201.07 \times 106 \mathrm{~m} 3$, and a sediment yield of c. $224440 \mathrm{t}$ - 1 (6.35 × $105 \mathrm{~m} 3)$ (Cooper 1991) but, unlike the Thukela River estuary, it is not permanently open to the ocean; during periods of low flow (e.g. during the dry season), the mouth can become closed. The KZN region receives c. 1 000-1200 mm y- 1 of rainfall (Day 1981) and has well-defined wet (J anuary-March) and dry (J uly- September) seasons. The peak of the wet season is in J anuary, with a mean monthly precipitation of $118 \mathrm{~mm}$, whereas August is the driest month (39 mm; Hunter 1988). Thus, in the Thukela River, the highest flow is in February and the lowest in August.

\section{Sample collection}

Multiple field samples were collected over the course of several smaller studies. Collectively they provided a suite of sample types and seasons that facilitated a broader view of the biological functioning of the bight. However, the sampling effort was not equal between seasons (see Appendix 1 for further details). Demersal organisms were collected on four occasions, twice during the wet season (J anuary 2009 and 2010) and twice during the dry season (August 2008 and 2010). Samples were collected from one-hour demersal trawls towed at a speed of 2.5 knots, with $50 \mathrm{~mm}$ stretched mesh in the codend, conducted using commercial trawlers; the FV Ocean Surf (2008 dry season) and the FV Ocean Spray (in all other seasons) (the trawling procedure is detailed in Fennessy [2016]). Trawl locations were chosen to coincide with the prawn trawling grounds on the bank (Figure 1). Species to be collected were pre-selected based on their likely frequency of occurrence (as anticipated by STF from prior experience of the fishery) and were stored and prepared according to de Lecea et al. (2011). A total of 11 species were collected in sufficient numbers per season/year to permit comparisons, namely seven teleosts (Atrobucca nibe, Cynoglossus attenuatus, C. lida, Johnius dorsalis (dussumieri), Otolithes ruber, Pomadasys olivaceum and Saurida undosquamis) and four decapods (Metapenaeus monoceros, Penaeus indicus, Portunus hastatoides and P. sanguinolentus) (Appendix 1). Particulate organic matter (POM) samples were collected from the Thukela Estuary and Matigulu Estuary mouths during the last two hours of an outgoing spring low tide to ensure that riverine and not marine POM was 
collected. Three replicates of surface POM were collected on three occasions (each separated by about two weeks) in each of the wet and dry seasons in 2008, 2009 and 2010. Samples were collected in acid-washed 500-ml bottles and placed on ice in a dark coolbox for later laboratory processing within six hours of collection. Simultaneously, replicate sediment samples were collected by scraping the upper $2 \mathrm{~cm}$ of sediment, collected using a modified van Veen grab, into plastic jars. Marine POM samples were collected using a Sea-Bird 911+ CTD with 12 PVC Niskin bottles of 5 litres each attached to a rosette. The CTD was deployed from the research vessel RS Algoa during a synoptic survey of the bight that was conducted in both seasons of 2010, and sampling localities closely coincided with the 2010 trawl localities (Figure 1). Simultaneously, marine sediment samples were collected using a modified van Veen grab, which was used to collect sediment/ benthos samples for a different concurrent study (MacKay et al. 2016). A subsample of sediments was collected immediately from the top $2 \mathrm{~cm}$ layer at each site, placed in a sealed bag and frozen at $-20{ }^{\circ} \mathrm{C}$.

\section{Sample preparation and stable isotope analysis}

Demersal organisms were only partially defrosted prior to tissue sampling to keep leaching of cell contents to a minimum (de Lecea et al. 2011). For teleosts, muscle was collected from the caudal peduncle on the left side of the body. For decapods, muscle tissue collection was more varied; for the Natantia, the shell was first removed from the abdominal segment from where tissue was sampled, whereas for the Brachyura, adductor leg muscle tissue from inside the carapace was harvested. Care was taken to ensure that non-muscular tissue (skin, bone, exoskeleton, intestine) was excluded from the samples. Lipid extraction or lipid collection models were not applied, following Boecklen et al. (2011), who found insufficient variation $(0.64 \%$ o) in $813 \mathrm{C}$ of lipid-extracted and non-extracted muscle and bone tissue to justify the increased variation in $\delta 15 \mathrm{~N}$ values that usually occurs as a result of lipid extraction. In addition, de Lecea and de Charmoy (2015) demonstrated that the current mathematical isotope correction models available in the literature did not work with all the species in the bight. Muscle-tissue samples were placed immediately in an air-circulating oven and dried at $60{ }^{\circ} \mathrm{C}$ for $48 \mathrm{~h}$, then homogenised and weighed into tin capsules (SANTI ${ }^{\circledR}$ Analytical, Teufen, Switzerland); c. $1.00 \mathrm{mg}$ dry mass was required to yield sufficient $\delta 15 \mathrm{~N}$ and $\delta 13 \mathrm{C}$ for analysis. For POM, water volumes of $500 \mathrm{ml}$ (see Appendix 1) were filtered through precombusted ( $4 \mathrm{~h}$ at $450^{\circ} \mathrm{C}$ ) $40 \mathrm{~mm}$ diameter Whatman $\mathrm{GF} / \mathrm{F}$ filters. Filters containing OM were then frozen at $-20^{\circ} \mathrm{C}$ and stored. Prior to analysis, the samples were acidified with a $2 \% \mathrm{HCl}$ solution to prevent inorganic $\mathrm{CaCO} 3$ affecting organic $\delta 13 \mathrm{C}$ values (Lorrain et al. 2003), rinsed with Milli-Q water and oven-dried at $65^{\circ} \mathrm{C}$. The samples were analysed at the IsoEnvironmental isotope facility at Rhodes University, Grahamstown, South Africa, using an ANCA-SL elemental analyser coupled to a Europa Scientific 20-20 isotope ratio mass spectrometer (IRMS) (Sercon). Each batch of 96 combustions contained 34 known standards, 29 of which were beet sugar and ammonium sulphate (in-house standards) and 5 of which were certified protein standard casein (calibrated against International Atomic Energy Agency [IAEA] standards IAEA-CH-6 and IAEA-N-1). The analytical precision of the instrument used for muscle tissue was $0.09 \%$ or $15 \mathrm{~N} / 14 \mathrm{~N}$ and $0.08 \%$ o for $13 \mathrm{C} / 12 \mathrm{C}$ and, for OM filters, the precision was $0.07 \%$ for $15 \mathrm{~N} / 14 \mathrm{~N}$ and $0.11 \%$ o for $13 \mathrm{C} / 12 \mathrm{C}$. Sediment samples were placed in an air-circulation oven at $50{ }^{\circ} \mathrm{C}$ for $24 \mathrm{~h}$, ground to ensure homogenisation, 
acidified using $2 \% \mathrm{HCl}$ solution to isolate the $\mathrm{OM}$ within the sediments, rinsed with Milli-Q water and returned to the oven for desiccation. Samples were processed in the archaeometry laboratory at the University of Cape Town. They were combusted in a Flash EA 1112 series elemental analyser (Thermo Finnigan); the gases were passed to a Delta Plus XP IRMS (Thermo Electron) via a Conflo III gas control unit (Thermo Finnigan). A proteinaceous gel produced by Merck (Darmstadt), was used as a standard and was calibrated against the IAEA standards. The analytical precision of the instrument was $0.06 \%$ or $15 \mathrm{~N} / 14 \mathrm{~N}$ and $0.06 \%$ o for $13 \mathrm{C} / 12 \mathrm{C}$. Isotope ratios obtained from both instruments are given in the standard $\delta$ notation for element X (Epstein et al. 1953): $\mathrm{dX}(\%)=[($ Rsample - Rstandard $) /$ Rstandard 1] $\times 1000$ (1) where $R$ is the ratio of $15 \mathrm{~N}: 14 \mathrm{~N}$ or $13 \mathrm{C}: 12 \mathrm{C}$ in the sample (Rsample) and in the standard (Rstandard), expressed relative to the international standard (Sulzman 2007). Statistical analysis and mixing models For the samples collected in 2010, the Bayesian mixing model MixSir (version 1.0.4 with uninformative priors; Moore and Semmens 2008) was used to determine the proportional contribution of marine and riverine $\mathrm{OM}$ to the sediments of the bank and the contribution of OM and/ or sediment OM in the diet of demersal organisms. For sediment OM origin, mixing models were used to elucidate the role of riverine input, using riverine and marine POM isotope values as 'source' and marine sediments OM isotope values as 'consumer' with no applied fractionation factors. In the second case, in order to determine the origin of the OM that maintains the demersal organisms of the bank, Thukela and Matigulu riverine POM, as well as marine and sediment $\mathrm{OM}$, were set as 'sources' in the mixing model, while the demersal organisms were set as the 'consumers'. These organisms would not be feeding directly on the OM trapped in the sediments, and hence the trophic position calculated for each species by de Lecea et al. (2013), along with the one-step fractionation factors of $0.4 \%$ (SD 1.3) for $13 \mathrm{C}$ and $3.4 \%$ o (SD 1) for $15 \mathrm{~N}$ (Post 2002), were used to estimate appropriate enrichment factors. In both mixing-model cases, the maximum importance ratio was below 0.001 , suggesting that the models were effective in estimating the true posterior density (Moore and Semmens 2008). Results for MixSIR are presented as the median and the 5th and 95th confidence intervals. Non-mixing model statistics were calculated using R 2.12.0 (R Development Core Team 2010). The dataset collected for $2010 \mathrm{POM}$ stable isotope values and $\mathrm{C} / \mathrm{N}$ ratios was analysed using a Kruskal-Wallis non-parametric test comparing Site (Matigulu, Thukela or marine) and Origin (marine vs riverine). A two-way ANOVA was used to compare the isotope values and $\mathrm{C} / \mathrm{N}$ ratio from the Thukela and Matigulu estuaries. Ordinarily riverine and marine sediments are not likely to be found together and as such riverine and marine sediment OM were not compared. It was decided that because there were only three years' worth of data collected (Appendix 1) the best approach was to compare the wet and dry seasons (2008, 2009 and 2010) for the riverine $\mathrm{OM}$ and the isotope values and $\mathrm{C} / \mathrm{N}$ ratios of organisms. Because the data were non-parametric, a Welch t-test was used. Ocean Data View 4 was used to produce bottom-contour maps using the GPS coordinates, marine sediment $\mathrm{C} / \mathrm{N}$ ratios and sediment mixing model results. 


\section{Results}

\section{Isotopic variables and $\mathrm{C} / \mathrm{N}$ ratios (2010)}

There were significant $\delta 13 \mathrm{C}$ signature differences in both seasons when comparing POM by site (Matigulu, Thukela and marine), and origin (marine vs riverine) (Table 1, Figure 2). Marine sediment $\delta 13 \mathrm{C}$ values were also significantly different to both riverine and marine $\mathrm{POM}$ values (Figure 2; Table 1). Marine sediment $\mathrm{C} / \mathrm{N}$ ratios were significantly different from marine POM C/N ratios (Figure 2; Table 1) in the wet season, but not from riverine POM $\mathrm{C} / \mathrm{N}$ ratios for either season. Values from marine sediments collected closer to the Matigulu Estuary mouth showed a lower $\mathrm{C} / \mathrm{N}$ ratio, while those marine sediments originating from closer to the Thukela Estuary mouth were generally higher (Figure 3a, b). The mixing models confirmed that the bank sediments in both seasons in 2010 were composed mainly of riverine $\mathrm{OM}$

Table 1: Comparative Kruskal-Wallis results for dry and wet seasons (a) comparing POM values by site (i.e. Matigulu, Thukela or marine) and origin (marine vs estuarine), and (b) comparing estuarine and marine POM isotopic signature, respectively, against marine sediment isotopic signature

\begin{tabular}{|c|c|c|c|c|c|c|c|c|c|}
\hline Season & Variable & $\chi^{2}$ & df & $p$ & Season & Variable & $\chi^{2}$ & df & $p$ \\
\hline (a) Dry & \multicolumn{4}{|c|}{ Site } & (b) Dry & \multicolumn{4}{|c|}{ Marine OM vs marine sediment } \\
\hline & $\delta^{15} \mathrm{~N}$ & 1.422 & 2 & 0.49 & & $\delta^{15} \mathrm{~N}$ & 1.03 & 1 & 0.31 \\
\hline & $\delta^{13} \mathrm{C}$ & 7.2 & 2 & $0.03^{*}$ & & $\delta^{13} \mathrm{C}$ & 6.6 & 1 & $0.01^{* *}$ \\
\hline & $\mathrm{C} / \mathrm{N}$ ratio & 5.42 & 2 & 0.06 & & $\mathrm{C} / \mathrm{N}$ ratio & 2.67 & 1 & 0.1 \\
\hline \multicolumn{5}{|c|}{ Origin } & & \multicolumn{4}{|c|}{ Estuarine OM vs marine sediment } \\
\hline & $\delta^{15} \mathrm{~N}$ & 1.07 & 1 & 0.3 & & $\delta^{15} \mathrm{~N}$ & 0.04 & 1 & 0.84 \\
\hline & $\delta^{13} \mathrm{C}$ & 5.4 & 1 & $0.02^{*}$ & & $\delta^{13} \mathrm{C}$ & 11 & 1 & $0.0009^{* * *}$ \\
\hline & $\mathrm{C} / \mathrm{N}$ ratio & 1.67 & 1 & 0.2 & & $\mathrm{C} / \mathrm{N}$ ratio & 0.09 & 1 & 0.76 \\
\hline Wet & \multicolumn{4}{|c|}{ Site } & Wet & \multicolumn{4}{|c|}{ Marine OM vs marine sediment } \\
\hline & $\delta^{15} \mathrm{~N}$ & 1.42 & 2 & 0.49 & & $\delta^{15} \mathrm{~N}$ & 1.44 & 1 & 0.23 \\
\hline & $\delta^{13} \mathrm{C}$ & 7.2 & 2 & $0.03^{*}$ & & $\delta^{13} \mathrm{C}$ & 5.34 & 1 & $0.02^{*}$ \\
\hline & $\mathrm{C} / \mathrm{N}$ ratio & 5.42 & 2 & 0.07 & & $\mathrm{C} / \mathrm{N}$ ratio & 5.34 & 1 & $0.02^{*}$ \\
\hline \multicolumn{6}{|c|}{ Origin } & \multicolumn{4}{|c|}{ Estuarine OM vs marine sediment } \\
\hline & $\delta^{15} \mathrm{~N}$ & 1.07 & 1 & 0.32 & & $\delta^{15} \mathrm{~N}$ & 0.13 & 1 & 0.72 \\
\hline & $\delta^{13} \mathrm{C}$ & 5.4 & 1 & $0.02^{*}$ & & $\delta^{13} \mathrm{C}$ & 8 & 1 & $0.005^{* *}$ \\
\hline & $\mathrm{C} / \mathrm{N}$ ratio & 1.67 & 1 & 0.2 & & $\mathrm{C} / \mathrm{N}$ ratio & 0.89 & 1 & 0.35 \\
\hline
\end{tabular}

\section{(Figure 3c, d), with the lowest values occurring north of the} Matigulu Estuary.

\section{The main biological drivers in the wet and dry seasons of 2010}

Because the OM collected in both seasons had clearly distinct isotopic values, it was possible to set it as a source for the mixing model, together with the marine sediment OM. This enabled measurement of which of these OM sources the organisms were (indirectly) dependent on. It is important to note that, in most cases, the organisms in this study would not have directly consumed OM or the OM in the sediments, in most cases, but rather would have obtained it by secondary (or tertiary) predation or by scavenging (i.e. OM would be passed through the food chain via an intermediate trophic level, e.g. benthic macrofauna). Mixing model results indicated that during the wet season the main biological driver for the decapod P. sanguinolentus and the teleosts A. nibe, C. attenuatus and J . dorsalis originated from the marine sediment OM (>90\%) (Table 2), which, as mentioned, was composed mainly of riverine OM. The OM sources for the teleosts O. ruber, P. olivaceus and S. 
undosquamis were a mixture of marine $\mathrm{POM}$ and marine sediment $\mathrm{OM}$, with $\mathrm{O}$. ruber obtaining most of its OM from a food web supported by the OM in the sediments, whereas Pomadasys olivaceus and S. undosquamis obtained most of their OM from marine-derived sources (Table 2). In the dry season the situation was similar, with decapod species depending mainly on OM originally derived from the sediments (Table 2). However, unlike the wet season, most of the teleost species appeared to obtain their OM from a mixture of organisms feeding either on sediment OM or marine POM, with sediment-derived OM being slightly more important. The exceptions were C. attenuatus and J. dorsalis, which were highly dependent on OM derived from the sediments, whereas C. lida was dependent mostly on OM derived from marine POM (Table 2). As with the wet season, S. undosquamis obtained most of its OM through preying on organisms that depended mainly on marine POM, with sediment OM playing a minor role (Table 2). 


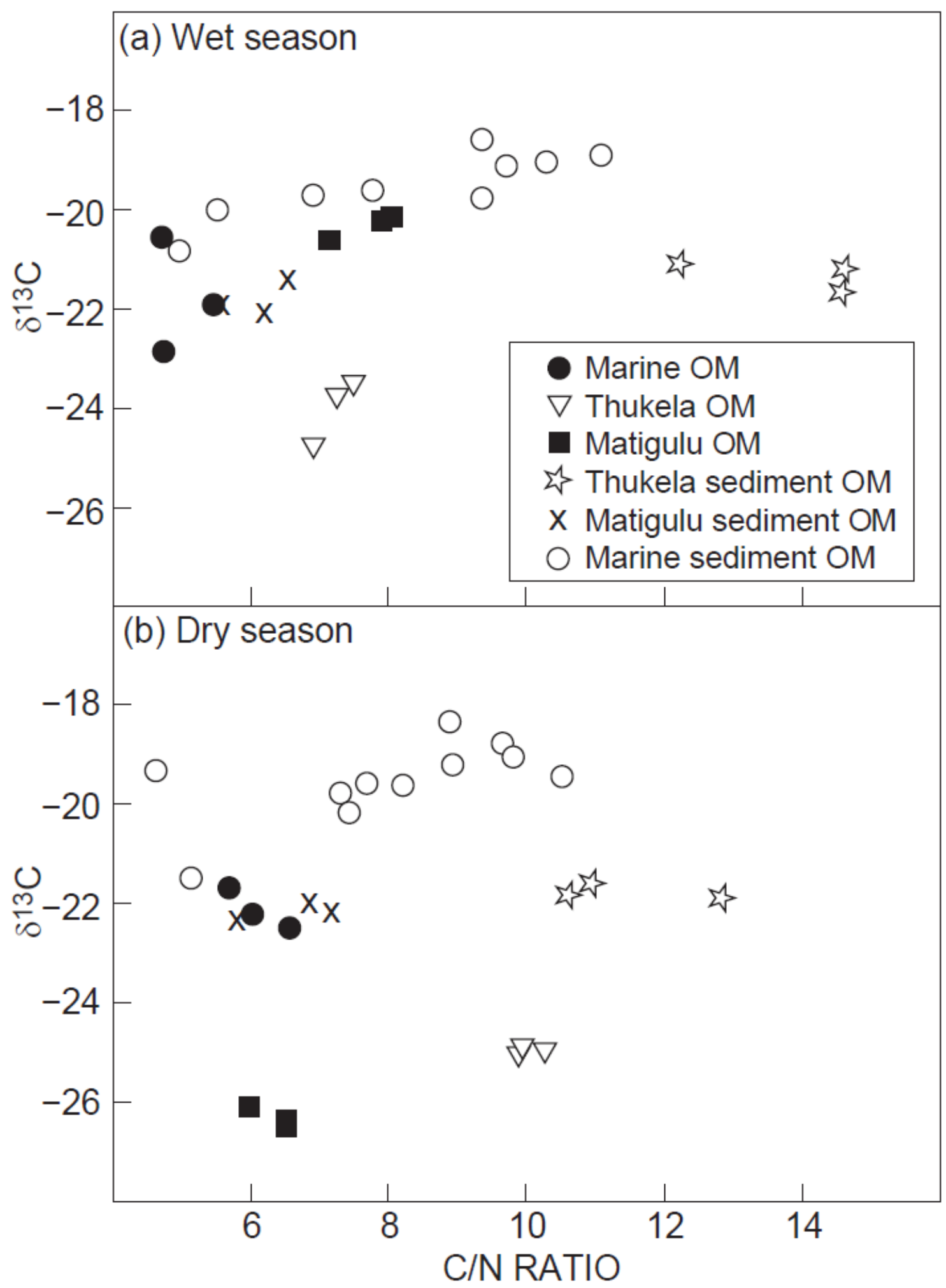

Figure 2: $\delta^{13} \mathrm{C}$ and $\mathrm{C} / \mathrm{N}$ ratio values for different sources of $\mathrm{OM}$ and sediments collected from the Matigulu and Thukela estuaries and the Thukela Bank (= marine) for (a) wet and (b) dry seasons 


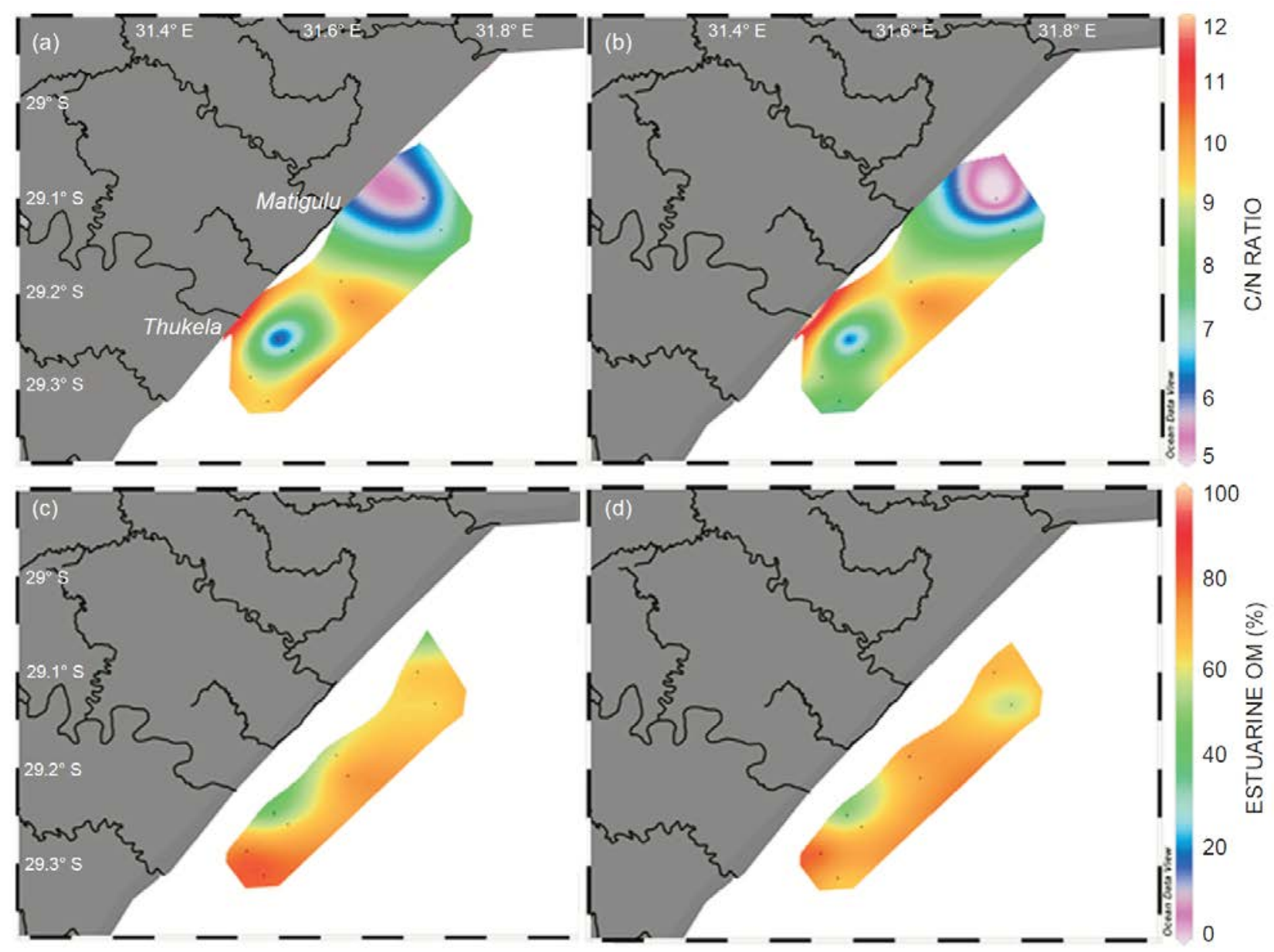

Figure 3: $(a, b) C / N$ ratio and (c, d) mixing model results for marine and estuary mouth sediment stations for the (a, c) wet and (b, d) dry seasons in 2010. Mixing model results show origin of OM (\%) in marine sediments

\section{Investigation of seasonal differences in riverine $\mathrm{OM}$ and animal tissue isotopic and $\mathrm{C} / \mathrm{N}$ ratios}

Riverine OM isotope values differed statistically between seasons for all years for the Thukela Estuary, with samples collected during the wet season being 13C-enriched and 15N-depleted compared to those of the dry season (Table 3). Neither Thukela nor Matigulu estuary OM showed statistically significant seasonality in $\mathrm{C} / \mathrm{N}$ ratios (Table 3; Welch t-test, $\mathrm{p}>0.05$ ). However, there were significant differences in $\mathrm{C} / \mathrm{N}$ ratios between the two estuaries (two-way ANOVA: $\mathrm{df}=1, \mathrm{SS}=7.85$, $\mathrm{MS}=7.85, \mathrm{~F}=4.59, \mathrm{p}<0.05$ ). In 2010, some of the organisms showed clear seasonal feeding habits (Table 2); thus it is expected that this should manifest in the organisms' isotopic values. Of the 11 demersal species collected in this study, two species, A. nibe and P. olivaceus, were significantly enriched in $\delta 15 \mathrm{~N}$ in the wet season compared to the dry season (Table 3). On the other hand, seven species were significantly enriched in $13 \mathrm{C}$ during the dry season (Table 3), with another two being more enriched but not significantly different. Five out of 11 organisms had significant differences in $\mathrm{C} / \mathrm{N}$ ratios between the wet and dry seasons (Table 3 ). 


\section{Discussion}

The aim of this study was to clarify the role played by the Thukela River in introducing OM into the nearby Thukela Bank ecosystem. It was found that, in both seasons (wet and dry) in 2010, riverine OM was the dominant OM input ( $>60 \%$ ) into the bank sediments. Mixing models revealed that organisms in the wet season were dependent on the OM of the bank. In the dry season, sediment OM (and, by implication, riverine OM) remained the most important driver for nine of the 11 species studied, but unlike in the wet season, marine POM also played an important role for the teleosts, perhaps highlighting a more opportunistic feeding behaviour and/ or greater reliance on pelagic food webs.

\begin{tabular}{|c|c|c|c|c|c|}
\hline Species & Description & Marine OM & Thukela OM & Matigulu OM & Marine sediment $\mathrm{OM}$ \\
\hline \multicolumn{6}{|c|}{ Wet season } \\
\hline Portunus sanguinolentus & Decapod & $0.01(0.00-0.05)$ & $0.01(0.00-0.04)$ & $0.01(0.00-0.04)$ & $0.96(0.92-0.99)$ \\
\hline Atrobucca nibe & Teleost & $0.04(0.00-0.97)$ & $0.01(0.00-0.06)$ & $0.02(0.00-0.08)$ & $0.91(0.00-0.98)$ \\
\hline Cynoglossus attenuatus & Teleost & $0.01(0.00-0.03)$ & $0.01(0.00-0.02)$ & $0.01(0.00-0.02)$ & $0.98(0.94-1.00)$ \\
\hline Johnius dorsalis & Teleost & $0.04(0.00-0.98)$ & $0.01(0.00-0.04)$ & $0.01(0.00-0.03)$ & $0.93(0.00-0.99)$ \\
\hline Otolithes ruber & Teleost & $0.64(0.53-0.77)$ & $0.01(0.00-0.04)$ & $0.03(0.00-0.20)$ & $0.31(0.05-0.45)$ \\
\hline Pomadasys olivaceus & Teleost & $0.27(0.02-0.31)$ & $0.01(0.00-0.04)$ & $0.05(0.00-0.17)$ & $0.64(0.58-0.86)$ \\
\hline Saurida undosquamis & Teleost & $0.74(0.62-0.84)$ & $0.01(0.00-0.05)$ & $0.06(0.00-0.20)$ & $0.17(0.02-0.35)$ \\
\hline \multicolumn{6}{|c|}{ Dry season } \\
\hline Metapenaeus monoceros & Decapod & $0.01(0.00-0.04)$ & $0.01(0.00-0.02)$ & $0.01(0.00-0.03)$ & $0.95(0.94-0.99)$ \\
\hline Panaeus indicus & Decapod & $0.01(0.00-0.08)$ & $0.01(0.00-0.04)$ & $0.01(0.00-0.04)$ & $0.95(0.88-0.98)$ \\
\hline Portunus sanguinolentus & Decapod & $0.01(0.00-0.02)$ & $0.00(0.00-0.02)$ & $0.00(0.00-0.02)$ & $0.96(0.94-0.98)$ \\
\hline Atrobucca nibe & Teleost & $0.45(0.01-0.94)$ & $0.01(0.00-0.03)$ & $0.01(0.00-0.03)$ & $0.53(0.01-0.94)$ \\
\hline Cynoglossus attenuatus & Teleost & $0.01(0.00-0.02)$ & $0.01(0.00-0.02)$ & $0.01(0.00-0.01)$ & $0.97(0.96-0.97)$ \\
\hline Cynoglossus lida & Teleost & $0.95(0.01-0.99)$ & $0.01(0.00-0.02)$ & $0.00(0.00-0.01)$ & $0.01(0.00-0.97)$ \\
\hline Johnius dorsalis & Teleost & $0.02(0.00-0.95)$ & $0.01(0.00-0.04)$ & $0.01(0.00-0.03)$ & $0.92(0.01-0.97)$ \\
\hline Otolithes ruber & Teleost & $0.48(0.42-0.56)$ & $0.00(0.00-0.01)$ & $0.00(0.00-0.01)$ & $0.51(0.43-0.58)$ \\
\hline Pomadasys olivaceus & Teleost & $0.45(0.39-0.51)$ & $0.00(0.00-0.01)$ & $0.00(0.00-0.01)$ & $0.54(0.49-0.61)$ \\
\hline Saurida undosquamis & Teleost & $0.67(0.38-0.97)$ & $0.01(0.00-0.04)$ & $0.01(0.00-0.04)$ & $0.31(0.01-0.60)$ \\
\hline
\end{tabular}

\section{Origin of OM in the sediments and marine POM seasonality}

Isotopic $\delta 13 \mathrm{C}$ values indicated that the marine sediment $\mathrm{OM}$ was distinct from both the marine and riverine OM sampled from the water column. Sediment OM must originate from either the marine or terrestrial environment. It is plausible, however, that the stable isotope values of the marine sediment OM represent mainly terrestrial plant detritus, with some marine phytoplankton accumulating and mixing in the sediments. In this regard, Goñi et al. (1998) found that, in marine areas with several OM inputs, the isotopic signature of the marine sediments did not represent one particular source, but a mixture of all sources. There was strong seasonality in the isotopic values of OM collected from the Thukela River mouth, with $15 \mathrm{~N}$ significantly enriched and $13 \mathrm{C}$ significantly depleted in the dry season, in comparison with the wet season. Seasonality in riverine isotopic values is common on account of the highly dynamic nature of estuaries (Faye et al. 2011), including in tropical and subtropical estuaries where wet and dry seasons are well defined (Olin et al. 2012). The relatively depleted OM 13C values in both seasons were likely due to the presence of C3 plant detritus from the Thukela River, where C3 plants grow in $75 \%$ of the catchment area (Harrison et al. 2001). The $813 \mathrm{C}$ of $\mathrm{C} 3$ plants ranges from $-22 \%$ o to $-33 \%$, and that of $\mathrm{C} 4$ plants ranges from $-9 \%$ o to $-16 \%$ (Huang et al. 2000), whereas for both C3 and C4 plants 
$\delta 15 \mathrm{~N}$ ranges from $-7 \%$ o to $7 \%$ o (Kelly 2000 ). The majority of $\mathrm{C} / \mathrm{N}$ ratios estimated in our study ranged between 8 and 10 . As with $\delta 13 \mathrm{C}$, these values do not fully represent either marine or riverine OM. Marine phytoplankton $\mathrm{C} / \mathrm{N}$ ratios are usually $<5$ due to the high levels of nitrogen accumulated in phytoplankton cells, whereas $\mathrm{C} / \mathrm{N}$ ratios of terrestrial plants are usually $\geq 11$ (Lamb et al. 2006). Hence our results might indicate a mixture of marine and terrestrial OM, in accordance with the findings of Ogrinc et al. (2005). However, given that bacterial degradation of terrestrial material in marine sediments can cause a lowering of $\mathrm{C} / \mathrm{N}$ ratios to values similar to those obtained in our study (Thornton and McManus 1994), it is considered likely that, although some mixing of marine and riverine $\mathrm{OM}$ may occur, the major source of $\mathrm{OM}$ to the bank is of riverine origin. Mixing models strengthened this notion by indicating that, although there was a mixture of marine and riverine $\mathrm{OM}$, the majority of $\mathrm{OM}$ accumulated in the sediments was of riverine origin.

\section{Identification of the OM driving the food web of the Thukela Bank}

A short literature review was undertaken to assess the diets of the organisms sampled for this study, the majority of which are known to feed on epibenthic organisms (Appendix 2). The mixing model results agree largely in that most species sampled in this study depended on the OM accumulating in the sediments, which suggests that macrobenthos (not sampled here) may play an important role in this food web. However, there were some exceptions O. ruber, P. olivaceus and S. undosquamis - which were instead highly dependent on marine POM in both seasons. Atrobucca nibe were also highly dependent on marine POM in the dry season but not in the wet, seemingly changing their feeding mode according to the season, a strategy that has been well described in other studies (Polis et al. 1995). Overall the main OM source driving the food web was the marine sediment OM, which, as discussed above, was mainly of riverine origin. This was followed in the dry season by marine POM becoming an important dietary supplement for a number of species.

\section{Organism seasonal stable isotope values and $\mathrm{C} / \mathrm{N}$ ratios}

Isotopic signatures in both $\mathrm{OM}$ and in organism tissue reflected a well-defined seasonal change. The upwelling cell in the northern part of the bight is not seasonal (Lutjeharms et al. 1989; Hutchings et al. 2010), and hence, unless there is another source of seasonal OM onto the bank that was not accounted for, it is likely that the Thukela and Matigulu River were the sources. 
Table 3: Welch t-test results comparing the combined wet and dry seasons of 2008,2009 and 2010 in terms of mean isotope and $\mathrm{C} / \mathrm{N}$ ratio values for estuarine POM and Thukela Bank organisms

\begin{tabular}{|c|c|c|c|c|c|c|c|}
\hline & Value tested & $t$ & df & $p$ & & Mean (SD) Wet & Mean (SD) Dry \\
\hline \multirow[t]{3}{*}{ POM (Thukela Estuary) } & $\delta^{15} \mathrm{~N}$ & 2.75 & 19.47 & 0.01 & $\star \star \star$ & $3.32(1.73)$ & $5.69(1.77)$ \\
\hline & $\delta^{13} \mathrm{C}$ & -4.82 & 10.10 & 0.00 & 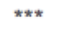 & $-21.48(1.93)$ & $-24.75(0.57)$ \\
\hline & $\mathrm{C} / \mathrm{N}$ & -0.01 & 15.18 & 0.99 & & $8.47(1.10)$ & $8.48(2.48)$ \\
\hline \multirow[t]{3}{*}{ POM (Matigulu Estuary) } & $\delta^{15} \mathrm{~N}$ & 0.23 & 16.19 & 0.82 & & $3.96(3.09)$ & $4.19(1.69)$ \\
\hline & $\delta^{13} \mathrm{C}$ & -1.28 & 22.31 & 0.21 & & $-22.18(1.41)$ & $-23.19(2.60)$ \\
\hline & $\mathrm{C} / \mathrm{N}$ & 0.48 & 23.88 & 0.64 & & $7.59(0.68)$ & $7.76(1.08)$ \\
\hline \multirow[t]{3}{*}{ Atrobucca nibe } & $8^{15} \mathrm{~N}$ & -2.97 & 9.80 & 0.01 & ** & $11.78(0.32)$ & $11.44(0.08)$ \\
\hline & $8^{13} \mathrm{C}$ & -0.86 & 10.98 & 0.41 & & $-16.84(0.31)$ & $16.94(0.13)$ \\
\hline & $\mathrm{C} / \mathrm{N}$ & -0.14 & 10.63 & 0.89 & & $3.22(0.09)$ & $3.22(0.03)$ \\
\hline \multirow[t]{3}{*}{ Cynoglossus attenuatus } & $\delta^{15} \mathrm{~N}$ & 0.44 & 32.65 & 0.67 & & $11.56(0.35)$ & $11.51(0.33)$ \\
\hline & $\delta^{13} \mathrm{C}$ & 1.51 & 32.99 & 0.14 & & $-16.13(0.30)$ & $-15.98(0.31)$ \\
\hline & $\mathrm{C} / \mathrm{N}$ & -0.43 & 32.94 & 0.67 & & $3.18(0.05)$ & $3.17(0.06)$ \\
\hline \multirow{3}{*}{ Cynoglossus lida } & $\delta^{15} \mathrm{~N}$ & -1.11 & 12.78 & 0.29 & & $11.65(0.12)$ & $11.48(0.46)$ \\
\hline & $\delta^{13} \mathrm{C}$ & -2.17 & 10.10 & 0.05 & & $-16.23(0.20)$ & $-16.66(0.56)$ \\
\hline & $\mathrm{C} / \mathrm{N}$ & 3.24 & 12.99 & 0.01 & $\star \star \star$ & $3.14(0.03)$ & $3.30(0.16)$ \\
\hline \multirow[t]{3}{*}{ Johnius dorsalis } & $\delta^{15} \mathrm{~N}$ & 2.04 & 33.67 & 0.06 & & $11.98(0.31)$ & $12.25(0.50)$ \\
\hline & $\delta^{13} \mathrm{C}$ & 3.30 & 36.90 & 0.00 & $\star \star \star$ & $-16.73(0.38)$ & $-16.31(0.42)$ \\
\hline & $\mathrm{C} / \mathrm{N}$ & 0.13 & 33.53 & 0.90 & & $3.27(0.06)$ & $3.27(0.10)$ \\
\hline \multirow[t]{3}{*}{ Otolithes ruber } & $\delta^{15} \mathrm{~N}$ & 0.38 & 44.23 & 0.70 & & $12.23(0.38)$ & $12.29(0.61)$ \\
\hline & $\delta^{13} \mathrm{C}$ & 1.94 & 47.36 & 0.06 & & $-16.62(0.45)$ & $-16.38(0.42)$ \\
\hline & $\mathrm{C} / \mathrm{N}$ & 0.33 & 48.22 & 0.74 & & $3.29(0.19)$ & $3.31(0.18)$ \\
\hline \multirow[t]{3}{*}{ Pomadasys olivaceus } & $\delta^{15} \mathrm{~N}$ & -2.21 & 30.55 & 0.03 & ${ }^{*}$ & $12.57(0.39)$ & $12.26(0.44)$ \\
\hline & $\delta^{13} \mathrm{C}$ & 3.59 & 34.74 & 0.00 & $* \star *$ & $-16.67(0.29)$ & $-16.24(0.44)$ \\
\hline & $\mathrm{C} / \mathrm{N}$ & -2.10 & 24.82 & $<0.05$ & * & $3.28(0.16)$ & $3.17(0.14)$ \\
\hline \multirow[t]{3}{*}{ Saurida undosquamis } & $\delta^{15} \mathrm{~N}$ & -0.38 & 16.55 & 0.71 & & $12.12(0.45)$ & $11.84(0.62)$ \\
\hline & $8^{13} \mathrm{C}$ & 2.62 & 9.41 & 0.03 & * & $-16.88(0.46)$ & $-16.31(0.33)$ \\
\hline & $\mathrm{C} / \mathrm{N}$ & -5.09 & 20.17 & $<0.01$ & 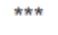 & $3.27(0.10)$ & $3.08(0.09)$ \\
\hline \multirow[t]{3}{*}{ Metapeneaus monoceros } & $\delta^{15} \mathrm{~N}$ & -0.51 & 16.73 & 0.62 & & $10.90(0.44)$ & $10.83(0.32)$ \\
\hline & $8^{13} \mathrm{C}$ & 4.66 & 31.85 & 0.00 & $* \star \star *$ & $-16.99(0.34)$ & $-16.30(0.54)$ \\
\hline & $\mathrm{C} / \mathrm{N}$ & -0.37 & 28.84 & 0.71 & & $3.27(0.10)$ & $3.22(0.05)$ \\
\hline \multirow[t]{3}{*}{ Penaeus indicus } & $8^{15} \mathrm{~N}$ & -0.97 & 28.92 & 0.34 & & $10.75(0.21)$ & $10.63(0.51)$ \\
\hline & $\delta^{13} \mathrm{C}$ & 3.19 & 9.58 & 0.01 & $\star \star \star$ & $-16.77(0.64)$ & $-16.06(0.31)$ \\
\hline & $\mathrm{C} / \mathrm{N}$ & -4.38 & 18.16 & $<0.01$ & $* * *$ & $3.31(0.05)$ & $3.21(0.07)$ \\
\hline \multirow[t]{3}{*}{ Portunus hastatoides } & $\delta^{15} \mathrm{~N}$ & -0.10 & 11.31 & 0.92 & & $10.56(0.58)$ & $10.53(0.37)$ \\
\hline & $\delta^{13} \mathrm{C}$ & 2.86 & 9.91 & 0.02 & * & $-17.60(0.46)$ & $-17.14(0.23)$ \\
\hline & $\mathrm{C} / \mathrm{N}$ & -0.82 & 11.95 & 0.43 & & $3.42(0.14)$ & $3.38(0.10)$ \\
\hline \multirow[t]{3}{*}{ Portunus sanguinolentus } & $\delta^{15} \mathrm{~N}$ & 1.97 & 35.89 & 0.06 & & $10.89(0.39)$ & $11.12(0.33)$ \\
\hline & $\delta^{13} \mathrm{C}$ & 4.59 & 30.81 & 0.00 & $\star \star \star \star$ & $-16.75(0.61)$ & $-16.02(0.35)$ \\
\hline & $\mathrm{C} / \mathrm{N}$ & -2.38 & 31.99 & 0.02 & * & $3.45(0.21)$ & $3.32(0.13)$ \\
\hline
\end{tabular}

${ }^{\star} p<0.05,{ }^{\star \star} p \leq 0.01,{ }^{\star \star \star} p<0.001$

Seasonal changes in organism isotopic response were the converse of changes in OM isotopic signature; $\mathrm{OM}$ was 13C-enriched in the wet season compared to the dry season, whereas organisms were 13C-enriched in the dry season. This may reflect a time-lag due to the fact that $\mathrm{OM}$ accumulates in the sediments and is consumed by organisms lower in the food web, which in turn are consumed by organisms at higher trophic levels, such as those in our study. In addition, time-lags in an organism's tissue reflecting the isotopic signature of its food are common on account of the period of time that organism tissue takes to reach equilibrium with that of the diet (Vanderklift and Ponsard 2003). Hence it is likely that a time-lag occurred in the assimilation by organism tissue of the isotopic signature of the OM released by the Thukela River. Overall there was some congruence between seasonal changes in OM and organism isotope values if isotopic incorporation times are taken into account. The time required for the $\delta 15 \mathrm{~N}$ value in an organism's tissue to reach equilibrium with the diet may differ from that for $\delta 13 \mathrm{C}$ values (Olive et al. 2003). Furthermore, it has been demonstrated that isotopic equilibrium between predator muscle tissue and that of the diet in the wild is limited due to seasonal changes or changes in prey item composition (Sweeting et al. 2005). 
In the current study, it appears that $13 \mathrm{C}$ from the diet was assimilated faster in the muscle tissue than $15 \mathrm{~N}$, because $\delta 13 \mathrm{C}$ values showed a clear seasonality for most species, whereas this was not the case for $\delta 15 \mathrm{~N}$ values. This could be because nitrogen isotopic values vary for a number of reasons, including different forms of nitrogen excretion (Minagawa and Wada 1984), isotopic fractionation (Vanderklift and Ponsard 2003) or owing to nitrogen-specific physiological or metabolic processes (Olive et al. 2003). In these instances, $\delta 15 \mathrm{~N}$ isotopic equilibrium in the tissue may not manifest, and rather than the signature showing either the current or the past diet, it may reflect a mixture of both (Gannes et al. 1997; Sweeting et al. 2005). Omnivory might also complicate the interpretation of the data, because organisms might reach an equilibrium that reflects a mixture of prey items at different trophic levels. Thompson et al. (2007) found that omnivory is common in marine systems, and that the higher the trophic level of an organism, the more common omnivory becomes. In our study, the majority of organisms are from higher trophic levels and are omnivorous (see Appendix 2). Five of the species sampled in this study had seasonal differences in $\mathrm{C} / \mathrm{N}$ ratios (C. lida, $\mathrm{P}$. olivaceum, P. indicus, P. sanguinolentus and S. undosquamis). It has been shown that high $\mathrm{C} / \mathrm{N}$ ratios ( $>3$ ) indicate a poor-quality diet, with a nitrogen-poor diet having a similar effect on tissues to that of fasting (Vanderklift and Ponsard 2003). Four of the five species, C. lida being the exception, had higher $\mathrm{C} / \mathrm{N}$ ratios in the wet than in the dry season, perhaps an indication that during the wet season there is a more varied and higher abundance of food. This study concurs with similar findings from other recent studies in the region (Ayers and Scharler 2011; de Lecea et al. 2013; de Lecea et al. 2015; Scharler et al. 2016) in highlighting the importance of riverine input in the ecology of the bight, which is contrary to previous understanding. Summary This study set out to understand the dependence of Thukela Bank organisms on organic input originating from the nearby estuaries. It was found that most of the OM accumulated in the sediments of the bank in the wet and dry seasons of 2010 was of riverine origin. Furthermore, it appears that, within a season, the food web supporting the majority of organisms under study was supported by the OM accumulated in the sediments. There were some exceptions that had higher dependency on marine POM, and the dependency of two species (A. nibe and P. olivaceus) differed between seasons. Considering seasonal stable isotope values for 2008, 2009 and 2010 combined, we found that the isotopic differences observed for OM (13C-enriched in the wet season compared with the dry season), were the converse of those seen for organisms (13C-enriched in the dry season). This discrepancy was attributed to a lag in the time taken for tissue to acquire the isotopic signature of the diet. $\mathrm{C} / \mathrm{N}$ ratios and mixing models provided supporting evidence for the view that OM from estuaries was the main driver of the studied food webs on the Thukela Bank. In conclusion, given the important role of the Thukela River, in particular, in providing input to demersal food webs (de Lecea et al. 2013; this study), and to fisheries (Lamberth et al. 2009; Turpie and Lamberth 2010), further consideration should be given to the impacts of freshwater impoundments planned for the Thukela catchment area (DWAF 2004), including their potential effects on the ecosystem of the KZN Bight and on two important fisheries in the region. Acknowledgements - We thank the African Coelacanth Ecosystem Programme, and the KZN Bight Thukela Bank Functioning Project (funded by the National Research Foundation of the South African Department of Science and Technology), for their financial contribution towards this study. We are grateful to the following: the late Dr Sven 
Kaehler from the IsoEnvironmental laboratory at Rhodes University for running the samples and providing useful comment; Desmond Hayes and Chris Wilkinson of the Oceanographic Research Institute for their assistance in the collection and processing of samples; Knud Sorenson, owner of the FV Ocean Spray, for kindly making his trawler available, and the crew for their help, and the officers and crew of the RS Algoa. AMdeL thanks Dr Jenny Huggett of the Department of Environmental Affairs for laboratory services. We acknowledge Rachel Cooper from the University of Cape Town for her editorial comments. 


\section{References}

Ayers MJ, Scharler UM. 2011. Use of sensitivity and comparative analyses in constructing plausible trophic mass-balance models of a data-limited marine ecosystem - the KwaZulu-Natal Bight, South Africa. J ournal of Marine Systems 88: 298- 311.

Beaulieu S. 2002. Accumulation and fate of phytodetritus on the sea floor. Oceanography and Marine Biology 40: 171- 232.

Bingel F, Avsar D. 1988. Food items of Saurida undosquamis in the northern Cilician Basin (eastern Mediterranean). Exploration Scientifique de la mer Méditerranée 31: 261.

Boecklen WJ, Yarnes CT, Cook BA, J ames AC. 2011. On the use of stable isotopes in trophic ecology. Annual Review of Ecology, Evolution, and Systematics 42: 411-440.

Bosman C, Uken R, Leuci R, Smith AM, Sinclair D. 2007. Shelf sediments off the Thukela River mouth: complex interaction between fluvial and oceanographic processes. South African J ournal of Science 103: 490- 492.

Bustamante RH, Branch GM, Eekhout S, Robertson B, Zoutendyk P, Schleyer M et al. 1995. Gradients of intertidal primary productivity around the coast of South Africa and their relationships with consumer biomass. Oecologia 102: 189- 201.

Cooper JAG. 1991. Shoreline changes on the Natal coast: Tugela River mouth to Cape St Lucia. NTRPC Report No. 76. Pietermaritzburg: Natal Town and Regional Planning Commission.

Darnaude AM. 2005. Fish ecology and terrestrial carbon use in coastal areas: implications for marine fish production. J ournal of Animal Ecology 74: 864- 876.

Darnaude AM, Salen-Picard C, Polunin NVC, Harmelin-Vivien ML. 2004. Trophodynamic linkage between river runoff and coastal fishery yield elucidated by stable isotope data in the Gulf of Lions (NW Mediterranean). Oecologia 138: 325- 332.

Day J H. 1981. Estuarine ecology with particular reference to southern Africa. Cape Town: AA Balkema. de Lecea AM, Cooper R. 2016. The importance of the Thukela River Estuary, East Coast of South Africa, for the biology of the near-shore environment and associated human aspects: a review. In: Diop S, Scheren P, Ferdinand Machiwa J (eds), Estuaries: a lifeline of ecosystem services in the Western Indian Ocean. Estuaries of the World. Switzerland: Springer International Publishing. pp 53- 65.

de Lecea AM, Cooper R, Smit AJ. 2015. Identifying the drivers of the pelagic ecosystem of an oligotrophic bight (Kwazulu-Natal, South Africa) using stable isotopes $(\delta 13 \mathrm{C}, \delta 15 \mathrm{~N}$ ) and C:N ratio analyses. Marine and Freshwater Research. DOI: $10.1071 / \mathrm{MF} 15256$.

de Lecea AM, de Charmoy L. 2015. Chemical lipid extraction or mathematical isotope correction models: should mathematical models be widely applied to marine species? Rapid Communications in Mass Spectrometry 29: 2013- 2025. 
de Lecea AM, Fennessy ST, Smit AJ. 2013. Processes controlling the benthic food web of a mesotrophic bight (KwaZulu-Natal, South Africa) revealed by stable isotope analysis. Marine Ecology Progress Series 484: 97- 114.

de Lecea AM, Smit AJ, Fennessy ST. 2011. The effects of freeze/ thaw periods and drying methods on isotopic and elemental carbon and nitrogen in marine organisms, raising questions on sample preparation. Rapid Communications in Mass Spectrometry 25: 3640- 3649.

Dominy CS, Haynes RJ , van Antwerpen R. 2001. Long-term effects of sugarcane production on soil quality in the south coast and the midlands areas of KwaZuluNatal. Proceedings of South Africa Sugar Technology Association 75: 222- 227.

DWAF (Department of Water Affairs and Forestry). 2004. Thukela Bank: impacts of flow scenarios on prawn and fish catch report - reserve determination study - Thukela River system. Report No. PBV000-00-10310. DWAF, Pretoria.

Epstein S, Buchsbaum R, Lowenstam HA, Urey HC. 1953. Revised carbonate-water isotopic temperature scale. Geological Society of America Bulletin 64: 13151326.

Fairbanks DHK, Benn GA. 2000. Identifying regional landscapes for conservation planning: a case study from KwaZulu-Natal, South Africa. Landscape and Urban Planning 50: 237- 257.

Faye D, Tito de Morais L, Raffray J, Sadio O, Thiaw OT, Le Loc'hF. 2011. Structure and seasonal variability of fish food webs in an estuarine tropical marine protected area (Senegal): evidence from stable isotope analysis. Estuarine, Coastal and Shelf Sciences 92: 607- 617.

Fennessy ST. 2000. Aspects of the biology of four species of Sciaenidae from the east coast of South Africa. Estuarine, Coastal and Shelf Science 50: 259- 269.

Fennessy ST. 2016. Subtropical demersal fish communities on soft sediments in the KwaZulu-Natal Bight, South Africa. In: Roberts MJ, Fennessy ST, Barlow RG (eds), Ecosystem processes in the KwaZulu-Natal Bight. African J ournal of Marine Science 38(Supplement): S169- S180.

Fennessy ST, Groeneveld J C. 1997. A review of the offshore trawl fishery for crustaceans on the east coast of South Africa. Fisheries Management and Ecology 4: 135- 147.

Fischer W, Sousa I, Silva C, De Freitas A, Poutiers J M, Schneider W et al. 1990. Fichas FAO de identificaçao de espécies para actividades de pesca. Guia de campo das espécies comerciais marinhas e de águas salobras de Moçambique. Rome: Food and Agriculture Organization.

Gannes LZ, O’Brien DM, Martínez del Rio C. 1997. Stable isotopes in animal ecology: assumptions, caveats, and a call for more laboratory experiments. Ecology 78: 1271- 1276.

George MJ . 1974. Food of the shrimp Metapenaeus Monoceros (Fabricius) caught from the backwaters. Indian J ournal of Fisheries 21: 495- 500. 
Gillanders BM, Kingsford MJ . 2002. Impact of changes in flow of freshwater on estuarine and open coastal habitats and the associated organisms. Oceanography and Marine Biology 40: 233- 309.

Goñi MA, Ruttenberg KC, Eglinton TI. 1998. A reassessment of the sources and importance of land-derived organic matter in surface sediments from the Gulf of Mexico. Geochimica et Cosmochimica Acta 62: 3055- 3075.

Harmelin-Vivien ML, Dierking J Banaru D, Fontaine MF, Arlhac D. 2010. Seasonal variation in stable $\mathrm{C}$ and $\mathrm{N}$ isotope ratios of the Rhone River inputs to the Mediterranean Sea. 2004- 2005. Biogeochemistry 100: 139- 150.

Harrison TD, Hohls DR, Meara TP, Webster MS. 2001. South African estuaries: catchment land-cover. National summary report prepared for the Department of Environmental Affairs and Tourism. Congella: Council for Scientific and Industrial Research.

Huang Y, Dupont L, Sarnthein M, Hayes J M, Eglinton G. 2000. Mapping of C4 plant input from North West Africa into North East Atlantic sediments. Geochimica et Cosmochimica Acta 64: 3505- 3513.

Hunter IT. 1988. Climate and weather off Natal. In: Schumann EH (ed.), Coastal ocean studies off Natal, South Africa. Lecture Notes on Coastal and Estuarine Studies 26. New York: Springer-Verlag. pp 178- 208.

Hutchings L, Morris T, van der Lingen CD, Lamberth SJ, Connell AD, Taljaard S, van Niekerk L. 2010. Ecosystem considerations of the KwaZulu-Natal sardine run. In: van der Lingen CD, Coetzee J C, Hutchings L (eds), The KwaZulu-Natal sardine run. African J ournal of Marine Science 32: 413- 421.

Kelly J F. 2000. Stable isotopes of carbon and nitrogen in the study of avian and mammalian trophic ecology. Canadian Journal of Zoology 78: 1-27. Lamb AL, Wilson GP, Leng MJ. 2006. A review of coastal palaeoclimate and relative sea-level reconstructions using $813 \mathrm{C}$ and $\mathrm{C} / \mathrm{N}$ ratios in organic material. Earth-Science Reviews 75: 29- 57.

Lamberth SJ, Drapeau L, Branch GM. 2009. The effects of altered freshwater inflows on catch rates of non-estuarine-dependent fish in a multispecies nearshore linefishery. Estuarine, Coastal and Shelf Science 84: 527- 538.

Lara RJ, Alder V, Franzosi CA, Kattner G. 2010. Characteristics of suspended particulate organic matter in the southwestern Atlantic: influence of temperature, nutrient and phytoplankton features on the stable isotope signature. J ournal of Marine Systems 79: 199-209.

Lorrain A, Savoye N, Chauvaud L, Paulet Y-M, Naulet N. 2003. Decarbonation and preservation method for the analysis of organic $\mathrm{C}$ and $\mathrm{N}$ contents and stable isotope ratios of low-carbonated suspended particulate material. Analytica Chimica Acta 491: 125- 133.

Lutjeharms J RE, Gründlingh ML, Carter RA. 1989. Topographically induced upwelling in the Natal Bight. South African J ournal of Science 85: 310-316. 
Lutjeharms JRE, Valentine HR, Van Ballegooyen RC. 2000. The hydrography and water masses of the Natal Bight, South Africa. Continental Shelf Research 20: 1907- 1939.

Maslowski J . 2003. Effects of trophic conditions on benthic macrofauna in the vicinity of the River Swina mouth, Pomerian Bay, southern Baltic Sea. Oceanologia 45: 41- 52.

MacKay CF, Untiedt CB, Hein L. 2016. Local habitat drivers of macrobenthos in the northern, central and southern KwaZulu- Natal Bight, South Africa. In: Roberts MJ , Fennessy ST, Barlow RG (eds), Ecosystem processes in the KwaZulu-Natal Bight. African Journal of Marine Science 38(Supplement): S105- S121.

Meyer AA, Lutjeharms J RE, de Villiers S. 2002. The nutrient characteristics of the Natal Bight, South Africa. J ournal of Marine Systems 35: 11- 37.

Minagawa M, Wada E. 1984. Stepwise enrichment of 15N along food chains: further evidence and the relation between $\delta 15 \mathrm{~N}$ and animal age. Geochimica et Cosmochimica Acta 48: 1135-1140.

Moore JW, Semmens BX. 2008. Incorporating uncertainty and prior information into stable isotope mixing models. Ecology Letters 11: 470- 480.

O'Brien GC, Swemmer R, Wepener V. 2009. Ecological integrity assessment of the fish assemblages of the Matikulu/Nyoni and Umvoti estuaries, KwaZuluNatal, South Africa. African J ournal of Aquatic Science 34: 293- 302.

Ogrinc N, Fontolan G, Faganeli J , Covelli S. 2005. Carbon and nitrogen isotope compositions of organic matter in coastal marine sediments (the Gulf of Trieste, N Adriatic Sea): indicators of sources and preservation. Marine Chemistry 95: 163- 181.

Olin J A, Hussey NE, Rush SA, Poulakis GR, Simpfendorfer CA, Heupel MR, Fisk AT. 2013. Seasonal variability in stable isotopes of estuarine consumers under different freshwater flow regimes. Marine Ecology Progress Series 487: 55-69.

Olin JA, Rush SA, MacNeil MA, Fisk AT. 2012. Isotopic ratios reveal mixed seasonal variation among fishes from two subtropical estuarine systems. Estuaries and Coasts 35: 811- 820.

Olive PJ W, Pinnegar J K, Polunin NVC, Richards G, Welch R. 2003. Isotope trophic-step fractionation: a dynamic equilibrium model. J ournal of Animal Ecology 72: 608-617.

Polis GA, Holt R, Menge BA, Winemiller KO. 1995. Time, space, and life history: influences on food webs. In: Polis GA, Winemiller KO (eds), Food-webs: integration of patterns and dynamics. New York: Chapman \& Hall. pp 435- 460.

Polis GA, Hurd SD. 1996. Linking marine and terrestrial food webs: allochthonous input from the ocean supports high secondary productivity on small islands and coastal land communities. The American Naturalist 147: 396- 423.

Pomerleau C, Winkler G, Sastri AR, Nelson RJ, Vagle S, Lesage V, Ferguson SH. 2011. Spatial patterns in zooplankton communities across the eastern Canadian sub- 
Arctic and Arctic waters: insights from stable carbon (813C) and nitrogen $(815 \mathrm{~N})$ isotope ratios. J ournal of Plankton Research 33: 17791792.

Post DM. 2002. Using stable isotopes to estimate trophic position: models, methods, and assumptions. Ecology 83: 703- 718.

R Development Core Team. 2010. R: a language and environment for statistical computing. Vienna: R Foundation for Statistical Computing.

Rajaguru A. 1992. Biology of two co-occurring tonguefishes, Cynoglossus arel and C. lida (Pleuronectiformes: Cynoglossidae), from Indian waters. Fisheries Bulletin 90: 328- 367.

Scharler UM, Ayers MJ, de Lecea AM, Pretorius M, Fennessy ST, Huggett JA et al. 2016. Riverine influence determines nearshore heterogeneity of nutrient (C, N, P) content and stoichiometry in the KwaZulu-Natal Bight, South Africa. African J ournal of Marine Science 38(Supplement): S193- S203.

Serrano X, Grosell M, Serafy JE. 2010. Salinity selection and preference of the grey snapper Lutjanus griseus: field and laboratory observations. J ournal of Fisheries Biology 76: 1592- 1608.

Sukumaran KK, Neelakatan B. 1997. Food and feeding of Portunus (Portunus) sanguinolentus (Herbst) and Portunus (Portunus) pelagicus (Linnaeus) (Brachyura: Portunidae) along Karnataka coast. Indian Journal of Marine Sciences 26: 35- 38.

Sulzman EW. 2007. Stable isotope chemistry and measurement: a primer. In: Michener R, Lajtha K (eds), Stable isotopes in ecology and environmental science (ecological methods and concepts). Oxford, UK: Blackwell Publishing Ltd. pp 1-21.

Sweeting CJ , J ennings S, Polunin NVC. 2005. Variance in isotopic signatures as a descriptor of tissue turnover and degree of omnivory. Functional Ecology 19: 777784.

Thompson RM, Hemberg M, Starzomski BM, Shurin JB. 2007. Trophic levels and trophic tangles: the prevalence of omnivory in real food webs. Ecology 88: 612617.

Thornton SF, McManus J. 1994. Application of organic carbon and nitrogen stable isotope and $\mathrm{C} / \mathrm{N}$ ratios as source indicators of organic matter provenance in estuarine systems: evidence from the Tay Estuary, Scotland. Estuarine, Coastal and Shelf Science 38: 219- 233.

Turpie J K, Lamberth SJ . 2010. Characteristics and value of the Thukela Banks crustacean and linefish fisheries, and the potential impacts of changes in river flow. African J ournal of Marine Science 32: 613- 624.

van der Elst RP, Adkin F. 1991. Marine linefish: priority species and research objectives in southern Africa. Special Publication No. 1. Durban: Oceanographic Research Institute.

Vanderklift MA, Ponsard S. 2003. Sources of variation in consumer-diet $\delta 15 \mathrm{~N}$ enrichment: a meta-analysis. Oecologia 136: 169- 182. 


\section{Whitfield AK. 2005. Fishes and freshwater in southern African estuaries - a review. Aquatic Living Resources 18: 275- 289.}

Appendix 1: Number of samples (total suspended solids [TSS for POM analysis] and sediments) and number of organisms collected from trawls conducted in different years and seasons. Note that marine TSS and sediments were only collected in the wet and dry seasons of $2010 ; \mathrm{n} / \mathrm{a}=$ no data

\begin{tabular}{|c|c|c|c|c|c|c|}
\hline \multirow{2}{*}{ Sample type/species } & \multicolumn{2}{|c|}{2008} & \multicolumn{2}{|c|}{2009} & \multicolumn{2}{|c|}{2010} \\
\hline & Wet & Dry & Wet & Dry & Wet & Dry \\
\hline Marine TSS & $n / a$ & $\mathrm{n} / \mathrm{a}$ & $n / a$ & $\mathrm{n} / \mathrm{a}$ & 3 & 3 \\
\hline Marine sediment & $\mathrm{n} / \mathrm{a}$ & $\mathrm{n} / \mathrm{a}$ & $\mathrm{n} / \mathrm{a}$ & $\mathrm{n} / \mathrm{a}$ & 9 & 11 \\
\hline Thukela TSS & 6 & 6 & 3 & 3 & 3 & 3 \\
\hline Thukela sediment & 3 & 3 & 3 & 3 & 3 & 3 \\
\hline Matigulu TSS & 6 & 6 & 3 & 3 & 3 & 3 \\
\hline Matigulu sediment & 3 & 3 & 3 & 3 & 3 & 3 \\
\hline Metapenaeus monoceros & $n / a$ & 18 & 12 & $\mathrm{n} / \mathrm{a}$ & $\mathrm{n} / \mathrm{a}$ & 6 \\
\hline Panaeus indicus & $\mathrm{n} / \mathrm{a}$ & 19 & 9 & $n / a$ & $\mathrm{n} / \mathrm{a}$ & 3 \\
\hline Portunus hastatoides & $\mathrm{n} / \mathrm{a}$ & 19 & 9 & $\mathrm{n} / \mathrm{a}$ & $\mathrm{n} / \mathrm{a}$ & $\mathrm{n} / \mathrm{a}$ \\
\hline Portunus sanguinolentus & $\mathrm{n} / \mathrm{a}$ & 10 & 14 & $\mathrm{n} / \mathrm{a}$ & 6 & 8 \\
\hline Atrobucca nibe & $n / a$ & 1 & 6 & $\mathrm{n} / \mathrm{a}$ & 3 & 3 \\
\hline Cynoglossus attenuatus & $\mathrm{n} / \mathrm{a}$ & 12 & 8 & $\mathrm{n} / \mathrm{a}$ & 9 & 6 \\
\hline Cynoglossus lida & $\mathrm{n} / \mathrm{a}$ & 6 & 3 & $\mathrm{n} / \mathrm{a}$ & $\mathrm{n} / \mathrm{a}$ & 6 \\
\hline Johnius dorsalis & $\mathrm{n} / \mathrm{a}$ & 18 & 12 & $\mathrm{n} / \mathrm{a}$ & 6 & 3 \\
\hline Otolithes ruber & $\mathrm{n} / \mathrm{a}$ & 18 & 18 & $\mathrm{n} / \mathrm{a}$ & 6 & 9 \\
\hline Pomadasys olivaceus & $\mathrm{n} / \mathrm{a}$ & 14 & 8 & $\mathrm{n} / \mathrm{a}$ & $\mathrm{n} / \mathrm{a}$ & 6 \\
\hline Saurida undosquamis & $\mathrm{n} / \mathrm{a}$ & 14 & 6 & $\mathrm{n} / \mathrm{a}$ & 2 & 6 \\
\hline
\end{tabular}

Appendix 2: General prey items, determined from the literature, for species collected on the Thukela Bank in the wet and dry seasons of $2010 ; \mathrm{n} / \mathrm{a}=$ no data

\begin{tabular}{|c|c|c|c|}
\hline Species & Description & General prey items & Reference \\
\hline Atrobucca nibe & Teleost & $\begin{array}{l}\text { Crustacea: Mysidacea, Natantia, Anomura; Cephalopoda; } \\
\text { Osteichthyes }\end{array}$ & Fennessy (2000) \\
\hline Cynoglossus attenuatus & Teleost & Benthic invertebrates & Fischer et al. (1990) \\
\hline Cynoglossus lida & Teleost & $\begin{array}{l}\text { Bivalvia; Cnidaria; Crustacea: prawns (Lucifer spp.), } \\
\text { Amphipoda, diverse Brachyura, Isopoda, Copepoda; } \\
\text { Asteroidea; Gastropoda; Osteichthyes; Polychaeta. Other } \\
\text { prey items include diverse zoobenthos, diatoms, benthic } \\
\text { algae and fish eggs }\end{array}$ & Rajaguru (1992) \\
\hline Johnius dorsalis & Teleost & $\begin{array}{l}\text { Polychaeta; Crustacea: Copepoda, Ostracoda, Mysidacea, } \\
\text { Stomatopoda, Natantia, Anomura, Brachyura; Cephalopoda; } \\
\text { Pelecypoda; Osteichthyes }\end{array}$ & Fennessy (2000) \\
\hline Metapenaeus monoceros & Decapod & $\begin{array}{l}\text { Crustacea: Copepoda, Mysidacea, Tanaidacea, Amphipoda, } \\
\text { decapod larvae; vegetable matter; diatoms; Polychaeta; } \\
\text { detritus }\end{array}$ & George (1974) \\
\hline Otolithes ruber & Teleost & $\begin{array}{l}\text { Crustacea: Natantia, Brachyura, Mysidacea, Stomatopda, } \\
\text { Anomura; Osteichthyes; Cephalopoda; Polychaeta; } \\
\text { Pelecypoda; vegetation; prawns; Acetes; Squilla; apogonid } \\
\text { fishes and juvenile sciaenids }\end{array}$ & Fennessy (2000) \\
\hline Penaeus indicus & Decapod & $\mathrm{n} / \mathrm{a}$ & \\
\hline Pomadasys olivaceus & Teleost & $\begin{array}{l}\text { Benthic Crustacea, and a variety of other invertebrates, but } \\
\text { not Annelida }\end{array}$ & $\begin{array}{l}\text { van der Elst and Adkin } \\
\text { (1991) }\end{array}$ \\
\hline Portunus sanguinolentus & Decapod & $\begin{array}{l}\text { Predator of slow-moving benthic macroinvertebrates. } \\
\text { Preference for crustaceans and molluscs. Females prefer } \\
\text { Osteichthyes in addition to Crustacea. Although fish } \\
\text { remains are important, it is unlikely that this species can } \\
\text { actively hunt healthy fish }\end{array}$ & $\begin{array}{l}\text { Sukumaran and } \\
\text { Neelakantan (1997) }\end{array}$ \\
\hline Saurida undosquamis & Teleost & $\begin{array}{l}\text { Osteichthyes; Crustacea: shrimp/prawn, Penaeus spp., } \\
\text { Stolephorus sp., crabs; Cephalopoda: octopus, squid/ } \\
\text { cuttlefish; other molluscs; fish eggs and larvae }\end{array}$ & Bingel and Avsar (1988) \\
\hline
\end{tabular}

